\title{
A giant dumbbell-shaped primitive neuroectodermal tumor in the brain
}

Figure 1 Dumbbell-shaped mass measuring $8 \times 10 \mathrm{~cm}$

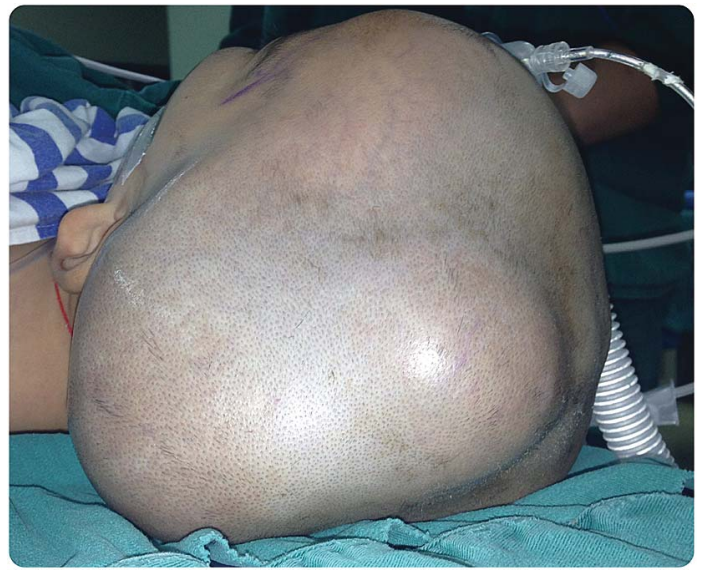

Image after the hair removal showing a giant dumbbell-shaped mass in the left occipitoparietal region.

A 5-year-old girl presented with an $8 \times 10$-cm dumbbell-shaped mass in her left occipitoparietal region (figure 1). A preoperative $\mathrm{CT}$ angiogram demonstrated a large subcutaneous mass with abundant blood vessels (figure 2A). MRI revealed a giant extracranial-intracranial space-occupying lesion (figure 2, B-D). After endovascular embolization, we resected the tumor (figure $2 \mathrm{E}$ ). The postoperative pathologic diagnosis was primitive neuroectodermal tumor (figure 2F). Primitive neuroectodermal tumor extension to the brain is rare; imaging is not pathognomonic and requires confirmation by pathology. Early intervention is preferable.

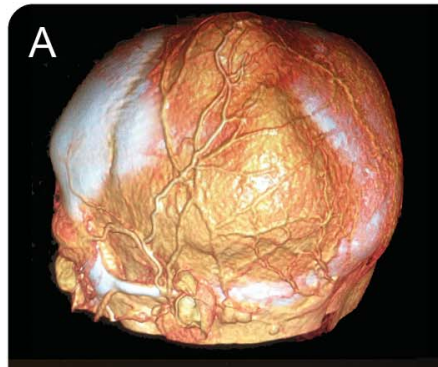

B

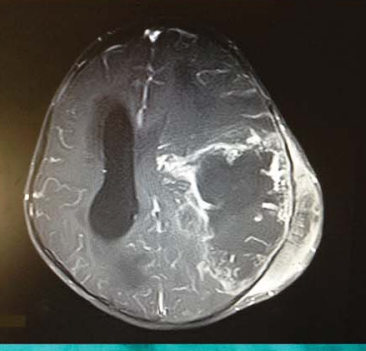

C
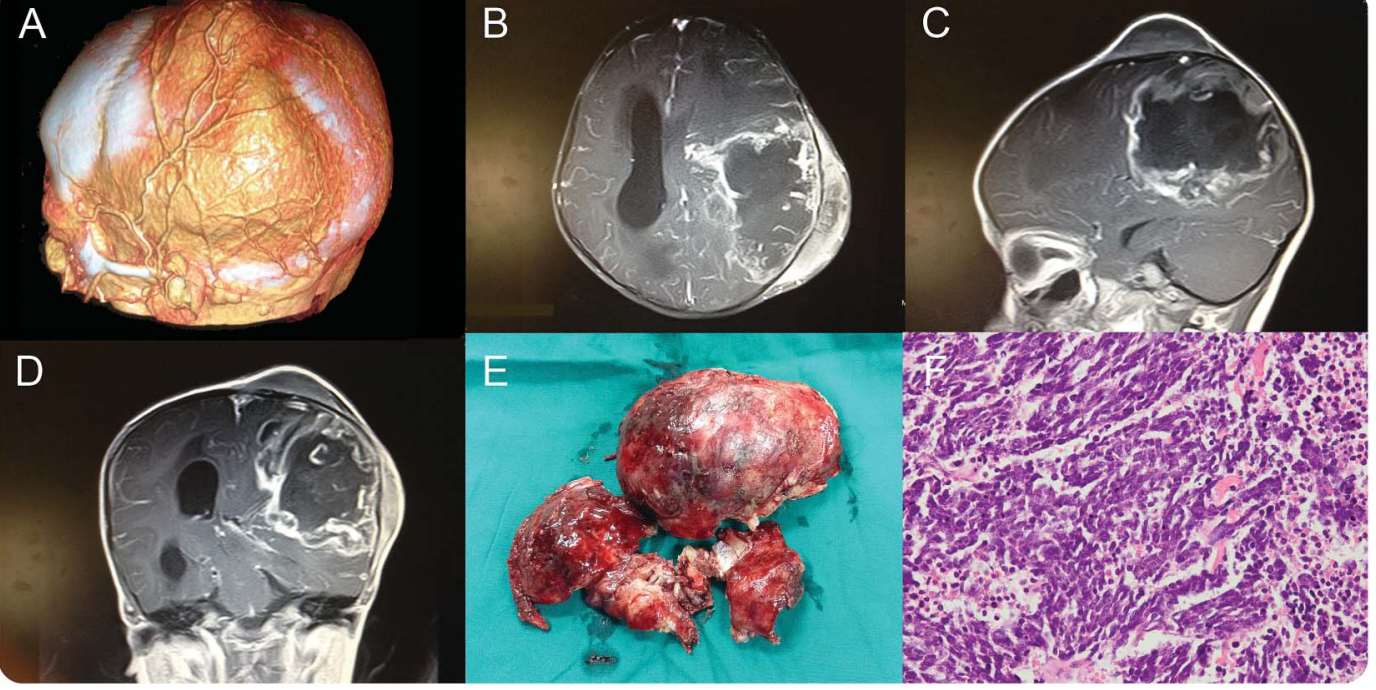

(A) Preoperative CT angiogram showing the skull involvement and superficial blood supply of the mass. (B-D) Preoperative MRI showing the intracranial involvement of the same tumor. (E) Gross specimen of the resected tumor. (F) Pathologic image of the tumor (hematoxylin \& eosin, $\times 400$ ). 


\section{Translate Today's Discoveries into Tomorrow's Clinic at 2017 Breakthroughs in Neurology Conference}

Get a year-in-review of the latest science and education while earning up to $27 \mathrm{CME}$ — with 11.25 qualifying for self-assessment CME_-at the 2017 Breakthroughs in Neurology Conference, set for January 13-16 at the beautiful Sheraton Grand at Wild Horse Pass. Secure your spot today: AAN.com/view/breakthroughs.

\section{WriteClick ${ }^{\circledR}$ rapid online correspondence}

Have a comment on a recent $N e u r o l o g y{ }^{\circledR}$ article you would like to share? Now it is easier and more convenient. Neurology.org has launched WriteClick on the home page and sidebars of each article to encourage remarks and debate among users.

WriteClick is restricted to comments about studies published in Neurology within the last eight weeks.

Learn more at Neurology.org/letters

\section{Minutes Pack a Punch}

\section{Neurology ${ }^{\circledR}$ Podcasts}

- Interviews with top experts on new clinical research in neurology

- Editorial comments on selected articles

- Convenient-listen during your commute, at your desk, or even at the gym

- On demand-it's there when you want it

- Fun and engaging

- New topic each week

- FREE

Listen now at www.aan.com/podcast 


\section{Neurology}

\section{A giant dumbbell-shaped primitive neuroectodermal tumor in the brain Zhi Gang Lan, Mao Jun Chen, Jin Li, et al. Neurology 2016;87;2495-2496 \\ DOI 10.1212/WNL.0000000000003411}

\section{This information is current as of December 5, 2016}

\section{Updated Information \& Services}

\section{Subspecialty Collections}

Permissions \& Licensing

\section{Reprints}

including high resolution figures, can be found at: http://n.neurology.org/content/87/23/2495.full

This article, along with others on similar topics, appears in the following collection(s):

\section{Primary brain tumor}

http://n.neurology.org/cgi/collection/primary_brain_tumor

Information about reproducing this article in parts (figures,tables) or in its entirety can be found online at:

http://www.neurology.org/about/about_the_journal\#permissions

Information about ordering reprints can be found online: http://n.neurology.org/subscribers/advertise

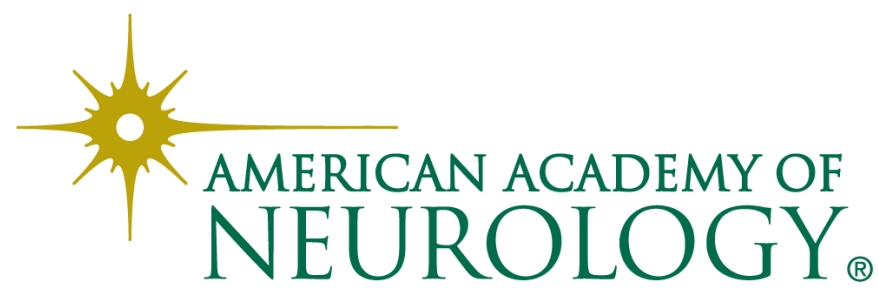

